\title{
Adopting US-GAAP Or IASB Accounting Standards By The Arab Countries
}

Taisier A. Zoubi, (E-mail: tzoubi@ausharjah.edu), American University of Sharjah, UAE

Osamah Al-Khazali, (E-mail: kazali@ausharjah.edu), American University of Sharjah, UAE

\begin{abstract}
This paper examines whether Arab countries have adopted the standards issued by the International Accounting Standards Board (IASB) or the US-GAAP. The results of this study show that companies in the Arab world use different accounting rules and regulations for measurement, recognition, and disclosures of financial position and results of operation. Consequently, comparability of the financial results of different companies in different countries in the Arab world is impaired. We recommend adopting financial accounting standards issued by the IASB. Our study shows that adopting IASB standards has a positive impact on the economic development of the Arab countries.
\end{abstract}

\subsection{Introduction}

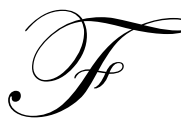

inancial Accounting standards are used to prepare the financial statements. Financial accounting standards consist of principles, methods, assumptions, and constraints. Companies in the Arab world have the option of selecting from many different standards. Companies in Arab countries could use the accounting standards of the nation where they are located, if that country has accounting standards. A second option is to select another country's accounting standards, such as United States GAAP, British accounting standards, or French accounting standards. A third alternative is to adopt the international accounting standards established by the International Accounting Standards Board (IASB).

A number of studies have been conducted to assess the impact and the adoption of western accounting systems and the IASB on individual developing countries in general (e.g., Samuels \& Oliga, 1982; Briston \& ElShker, 1984; Briston and Wallace, 1990; Kirby, 2001) and the Arab countries in particular (see Merei, 1985; Haqiqi and Poneranz, 1987; Mutter,1993; Baydoun and Willett, 1995; Joshi and Al-Bastaki, 1999; and Abd-Elsalam and Weetman, 2003).

This paper examines whether Arab countries have adopted the International Accounting Standards issued by IASB or the US-Generally Accepted Accounting Principles (GAAP). The paper is organized as follows: Section two will review the prior literature. Section three will outline the differences and similarities between IAS and USGAAP. Section four will examine the needs for financial accounting standards by the Arab countries. Section five presents data collection, sources, methodology, and analysis. Section six discusses the summary and conclusion of the study.

\subsection{Review of the Relevant Literature}

Prior research has examined the adoption of the IASB standards by a single Arab country or companies located in one Arab nation (Merei, 1985; Haqiqi and Poneranz, 1987; Baydoun and Willett, 1995; Joshi and AlBastaki, 1999; Joshi and Al-Mudhaki, 2001; and Abd-Elsalam and Weetman, 2003) or two or more Arab nations (see Kantor, Roberts, and Salter 1995). 
Merei (1985) studied the financial accounting practices in Saudi Arabia and found that some of the sampled firms followed the US-GAAP standards while other firms followed the IASB standards. A small number of firms used either the British or the French financial accounting system.

Haqiqi and Pneranz (1987) reviewed the financial accounting practices of the Islamic Financial Institutions in the Arab world. Their results indicate that the majority of the Islamic Financial Institutions adopted the USGAAP standards. Mutter (1993) examined the compliance of Jordanian companies to the IASB disclosure requirements and found that the majority of his sampled firms complied with the disclosure requirements of the IASB.

Baydoun and Willet (1995) examined the impact of the French Unified Accounting Systems on Lebanon accounting practices. Their results indicate that most of the financial accounting reporting practices of firms in Lebanon followed the French accounting systems. However, a few firms used other accounting standards such as IASB, US-GAAP, or British accounting systems.

Kantor, Roberts, and Salter (1995) studied financial reporting practices in Egypt, Saudi Arabia, and the United Arab Emirates. The results of their study showed that there were similarities in the financial reporting practices among the three nations. Furthermore, the financial reporting systems in the three countries adopted the French accounting system.

Joshi and Al-Mudhaki (2001) examined the compliance of companies listed in the stock exchange of Bahrain with IAS-1. Their results showed that there was a high degree of compliance with IAS-1 for the sampled firms. Abdel-Elsalam and Weetman (2003) reviewed the application of IASB standards in Egypt by examining the effect of familiarity and the availability of the IASB standards in Arabic. Their results show that the level of compliance to the IASB standards is very low when the firms are not familiar with the standards. The translation of the standards to the Arabic language is positively impacted the degree of compliance.

Based on our review of the prior research which examined financial reporting practices of the Arab countries, we concluded that the prior studies are lacking in the sense that none of them have attempted to examine the adoption of either the IASB accounting standards or US-GAAP standards by all the Arab countries.. Therefore, this study will try to fill this void in the literature by examining which accounting standards have been adopted by the entire Arab world. More specifically, we examined whether each country in the Arab world adopted the IASB standards or the US-GAAP.

\subsection{Differences and Similarities Between IAS and US-GAAP}

The objectives of the International Accounting Standards Board (IASB) are: (a) to formulate and publish in the public interest accounting standards to be observed in the presentation of financial statements and to promote their worldwide acceptance and observance; and (b) to work generally for the improvement and harmonization of regulations, accounting standards and procedures relating to the presentation of financial statements (IASC Constitution, October 1992).

Harmonization consists of recognizing the differences in the accounting standards among countries and attempting to reconcile them with other countries' objectives. Samuels and Oliga (1982) argued that financial accounting standards should be established to meet the needs of the local as well as the international business community.

The US-GAAP is a common set of standards and procedures developed in the United States by the accounting profession. It is commonly believed that the objective of the US-GAAP is to serve as a general guide to the accounting practitioner in accumulating and reporting the financial information of a business enterprise.

The relative quality of the financial accounting standards established by the IASB and the US-FASB has been the subject of debate in many prior studies (Harris \& Muller III, 1999; and Luez, 2003). For example, Harris 
and Muller III (1999) found that there were no significant differences between IASB and US-GAAP standards in the calculations of net income and stockholders equity.

The FASB (1999) examined the differences between the IASB and the US-GAAP in three major areas: measurement, recognition, and accounting alternative. The FASB concluded that the IASB standards are less detailed and require fewer footnote disclosures, consequently the IASB standards are perceived to be of a lesser quality than the US-GAAP standards.

Biddle and Saudagaran (1991) argued that different financial accounting standards will produce different financial statements figures and disclosures. Hence, the financial statements users will be impacted differently. Doupnik and Salter (1993) contended that the choice among different foreign accounting systems is determined primarily by cultural heritage, economic affiliation, or colonization link.

Luez (2003) examined the differences in the information asymmetry (bid-ask spreads and shares turnover) of firms using International accounting standards (IAS) or US GAAP standards and found no significant differences in the bid-ask spread and share turnover across IAS and US-GAAP. Luez (2003) contended that IAS and US-GAAP should yield similar financial accounting quality numbers. Richardson and Hutchinson (1999) argued that IASB standards are mostly concerned with disclosures while US-GAAP emphasizes measurement in accounting.

\subsection{The Arab Countries' need for Financial Accounting Standards}

Overall, the financial reports are important to investors. The income statement is important because it reveals management's current and past success in creating and sustaining income. The balance sheet shows the firm's assets base, from which future income is generated, and liabilities and their due dates to creditors. The statement of cash flows is important in assessing the firm's ability to meet cash payments. Financial analysts use ratios for assisting users in evaluating the financial soundness of firms.

The financial reports provide relevant, reliable, and comparable financial information to the stock market participants which leads to better investment decisions. Consequently, efficient allocation of economic resources will be achieved and this will positively affect the stock markets. Furthermore, another important role of financial accounting reports is to improve corporate governance. Some have argued that financial accounting information in the developing countries, such as the Arab nations, are needed for planning at the macro level.

The financial reporting standards are crucial components of the infrastructure for developing domestic capital markets. A significant body of research shows that accounting reports are relevant to investors' buy and sell decisions. The importance of accounting reports for stock market investors has been demonstrated through capital market studies conducted in different countries in cross-country surveys of users (Choi \& Levich, 1991; Bhushan \& Lessard 1992).

Multinational lending institutions, such as the World Bank, have generally agreed that a well-functioning stock market provides the necessary ingredient for the economic growth of the developing countries. The relationship between accounting information and the growth of domestic securities markets is a crucial policy issue for developing countries that aims to boost capital inflows to their economies (Ndubizu \& Wallace, 2003). Walter (1993) contends that the accounting standards used for information production and disclosure is central to equity market development and to the ability to attract cross-border flows. He argues that the stronger the information infrastructure, the more attractive the stock market will be to foreign equity investors. Many Arab countries suffer from an investment-savings gap. This gap means that the funds available fall far short of the amount needed to stimulate economic development. To reduce the investment-savings gap, Arab countries should adopt accounting standards which will facilitate investment by foreigners in the Arab countries stock markets.

For most Arab countries, relying on their local stock markets as a means of raising large capital to finance local projects may not be sufficient approach. Hence, local firms in the Arab countries should seek foreign listings as a means of raising the needed capital. Foreign listing requires financial statements that are comparable to the 
country where the security market is located. Accounting reports are important considerations in stock market listing decisions.

The accounting literature suggests three different criteria for evaluating the adequacy of financial reporting by foreign stock markets: (1) availability, (2) reliability, and (3) comparability. Focusing on these criteria assists in highlighting areas for improvement and policy formulation. These criteria provide the focal point for developing benchmarks for comparing and improving the performance of financial reporting standards in developing countries (see Barth \& Clinch, 1996; Ndubizu \& Wallace, 2003).

The first criterion for evaluating financial reports is availability. Availability means that financial statements on publicly traded companies are adequate, timely and accessible by the stock market participants. In most Arab countries, data availability and data accessibility are limited. Additionally, there is a long period of delay between the year-end date of the financial statements and the date of their release to the public.

Reliability is the second criterion for evaluating financial statements. Reliability encompasses two requirements. First, financial accounting reports should be prepared on the basis of sound accounting standards. Second, necessary rules and regulations should be established to ensure compliance with the required accounting standards.

The third criterion relates to the comparability of financial statements. The differences in accounting methods used to prepare financial statements may represent a major problem in comparing the financial statements of different companies in different countries. Prior studies (Choi \& Levich, 1991; Bhushan \& Lessard, 1992; Walter, 1993) indicate that international accounting differences are viewed as important by international investors and are perceived to be barriers to international diversification.

Barth and Clinch (1996) investigated what happens to securities market performance when one country's accounting rules are different from another country's. They found that the tendency among traders was to buy and sell less in countries with vastly different accounting rules, as the cost of learning to assess the stock is very high. Their results also indicated that if one country makes its accounting rules similar to a second country's rules then investors in both countries will buy and sell stocks in both markets (locally and foreign). Consequently, prices of the stocks in both countries will reflect the true value, increased trading volume and reduce cost of capital.

There is continuing concern in practice with the lack of international comparability of corporate reports for investor purposes. This concern continues to be expressed by international financial analysts and professional accountancy organizations as well as by governments. The variety of measurement methods and disclosures impair effective comparison of financial position and performance.

Differences in treatment for some of the items that are reported in the financial statements may have a negative impact on profit and certain ratios and thus impair the ability of a local company to compete for capital. Different accounting rules produce incomparable results. Comparable financial statements would bring benefits to local and foreign companies. Comparable financial statements enable stock market participants to understand the strengths and weaknesses of relative profitability, liquidity and the financial power of one's company vis-à-vis its foreign competitors.

\subsection{Data collection, Sources, Methodology, and Analysis}

To conduct this study we compiled data from the following sources:

1. IASB data compiles list of member countries.

2. IMF country reports.

3. Central bank national accounting requirements of some countries.

4. Commercial banks and companies annual reports if available.

5. United Nations reports on each country. 
The results of the study for each Arab nation is summarized below:

- Algeria: Algerian accounting standards do not require the preparation of financial statements. The country does not set out the accounting treatment for many important transactions. Observance of existing standards is not effectively enforced.

- Bahrain: Companies in Bahrain are required to prepare financial statements in accordance with the IAS.

- $\quad$ Comoros: No specific financial accounting and reporting standards have been adopted.

- Djibouti: No specific financial accounting and reporting standards have been adopted.

- $\quad$ Egypt: Egyptian requirements are based on the Companies Law and the Capital Market Law, on Egyptian Accounting Standards of the Ministry of Finance, and on regulations of the Central Bank. There is also a formal reference in the law to the use of IAS when there are no Egyptian requirements. Egyptian Accounting Standards have been prepared to comply with the IAS.

- Iraq: No specific financial accounting and reporting standards have been adopted.

- Jordan: Banks must adopt the accounting standards issued by the International Accounting Standards Board.

- Kuwait: All accounting and reporting for corporate entities are subject to IAS. The IAS also governs the disclosure rules.

- Lebanon: Lebanon has established accounting and financial obligations by means of decrees. Annual financial reports must be realized in accordance with the current standard. The annual financial reports must include: a balance sheet, a profit and loss account, a cash flow statement.

- Libya: No specific financial accounting and reporting standards have been adopted.

- Mauritania: The Mauritania Accounting and Auditing Standards Committee develop accounting standards and guidelines locally. IAS are used as a guide.

- Morocco: Moroccan requirements are based on Law No. 9-88 and on the standards and regulations of the Ministry of Finance and the National Accounting Standards Board. IAS are used as a guide.

- Oman: IAS are mandatory in Oman. All companies are required to prepare financial statements in accordance with IAS.

- Palestine: Banks in Palestine follow the IAS. Companies are encouraged to adopt the International accounting standards.

- Qatar: Financial statements and disclosures of corporate entities in Qatar should follow the International Accounting Standards Board.

- Saudi Arabia: Saudi requirements are based on governmental Regulations for Companies and on accounting standards issued by the Saudi Organization of Certified Public Accountants (SOCPA). A limited number of accounting standards were issued by SOCPA. SOCPA stipulates that US- GAAP should be adopted for those issues not covered by the SOCPA Standards.

- $\quad$ Somalia: No specific financial accounting and reporting standards have been adopted. Companies should ensure that their accounts are produced in accordance with IAS.

- Sudan: No specific financial accounting and reporting standards have been adopted. Each bank must develop its system for keeping records and files related to domestic or foreign operations in such a manner as to facilitate presenting them to the concerned authorities when asked to do so.

- Syria: Syria has established its own accounting rules and regulations, which may not be in compliance with the IAS.

- $\quad$ Tunisia: Tunisian requirements are based on the Law of 30 December 1996 and on Standards issued by the National Accounting Council. Tunisian accounting may differ from that required by IAS because of the absence of specific Tunisian rules on recognition and measurement in many areas such as accounting for employee benefit obligations, deferred tax, and accounting for an issuer's financial instruments.

- United Arab Emirates: All banks, financial and investment companies have to prepare their financial results in accordance with the IAS

- Yemen: Yemen's banks have to present their financial statements according to IAS, thereby considerably improving the transparency of the sector. 
Based on the summary data, the following observations can be made

1. Bahrain, Jordan, Kuwait, Oman, Palestine, Qatar, United Arab Emirates, and Yemen follow the IAS rules, regulation, and disclosures. Companies in these countries should adhere to the IAS.

2. Egypt, Lebanon, Mauritania, Morocco, Syria, and Tunisia were developed their own national accounting standards, however, companies in those countries should use IAS when there are no national accounting requirements for specific accounting issues.

3. Algeria, Comoros, Djibouti, Iraq, Libya, Somalia, and Sudan have no specific financial accounting and reporting standards.

4. Saudi Arabia has established its own accounting standards. Saudi's accounting standards Authority stipulates that US GAAP should be adopted for those issues not covered by the Saudi's accounting regulations.

\subsection{Summary and Conclusion}

The results of this study show that companies in the Arab world use different accounting rules and regulations for measurement, recognition, and disclosures of financial position and results of operation. Consequently, comparability of the financial results of different companies in different countries in the Arab world is impaired. This will negatively impact foreign investments, foreign listing, and security markets. To resolve the issue of comparability and provide more reliable, accurate, and valid financial accounting information, Arab countries collectively should adopt the IAS.

Why should the Arab countries adopt the IASB standards? First, many countries in the world already use IASB standards. Adopting the IAS will facilitate capital movements and expand investment opportunities by companies located in the Arab countries. Furthermore, financial statements prepared by companies located in any Arab country will be comparable to the ones prepared by companies that exist within or outside the Arab world. As a result, foreign investments will be facilitated. The ability of national companies' to raise capital from outside will be enhanced. Finally, many Arab countries do not have codified financial accounting standards. By adopting the international accounting standards, the cost of set up and production of accounting standards will be eliminated.

\section{References}

1. Abd-Elsalam, O. and P.Weetman, 2003, "Introducing international accounting standards to an emerging capital market: Relative familiarity and language effect in Egypt", Journal of International Accounting, Auditing \& Taxation, 12, 63-84.

2. Barth, M. and G.Clinch, 1996, "International Accounting Differences and Their Relation to Share Prices: Evidence from U.K., Australian, and Canadian Firms", Contemporary Accounting Research, spring, 13, No. 1, 135-171.

3. Baydoun, N. and R. Willett, 1995, "Cultural Relevance of Western Accounting Systems to Developing Countries." ABACUS, 31, No. 1, 67-92.

4. Bhushan, R. and D. Lessard, 1992, “Coping with International Accounting Diversity: Fund Managers' Views on Disclosure, Reconciliation, and Harmonization." Journal of International Financial Management \& Accounting, Summer, 4, No. 2, 149-165.

5. Biddle, G. and S. Saudagaran, 1991, "Foreign stock listings: benefits, costs, and the accounting policy dilemma Accounting Horizons, " 5, No. 3, 69-81.

6. Briston, J., and A. El-Shker, 1984, "The Egyptian accounting system: A case study in western influence" The International Journal of Accounting Education and Research, 19, 129-155.

7. Briston, R. J., and R.S. Wallace, 1990, "Accounting education and corporate disclosure regulations in Tanzania," Research in Third World Accounting, 1.

8. Choi, F., and R. Levich 1991, "International Accounting Diversity: Does it Affect Market Participants?" July/August, 47, No. 4, 73-83.

9. Doupnik, T, and S.Salter, 1993, “An empirical test of a judgmental international classification of financial reporting practices.” Journal of International Business Studies, 24, No. 1, 41-61. 
10. Financial Accounting Standards Board, 1999 "The IASC-U.S. Comparison Project: A Report on the Similarities and Differences between IASC Standards and U.S. GAAP." $2^{\text {nd }}$ Edition.

11. Haqiqi, A.W., and F. Poneranz, 1987, "Accounting needs of Islamic Banking." Advances in International Accounting, 9, 153-168.

12. Harris, M.; K. Muller III, 1999, "The market valuation of IAS versus US-GAAP accounting measures using Form 20-F reconciliations.” Journal of Accounting \& Economics, January, 26, No. 3, 285-312.

13. International Accounting Standards Committee: IASC Constitution (approved by the Members of IASC on 11th October 1992)

14. Joshi, P. L. and H. Al-Bastaki, 1999, "Development and adoption of international accounting standards: Perception s of professional accountants in Bahrain" Asian Review of Accounting, 7, No. 2, 96-117.

15. Joshi, P.L., and A. Al-Mudhaki, 2001, "Empirical study of compliance with International Accounting Standards (IAS-1) by Stock Exchange listed companies in Bahrain," Journal of Financial Management and Analysis, 14, No. 2, 43-54.

16. Kantor, J., Roberts, C., and S. Salter, 1995, "Financial reporting practices in selected Arab countries: An empirical study of Egypt, Saudi Arabia, and the United Arab Emirates." International Studies of Management \& Organization, 25, No. 3, 31-44.

17. Kirby, A., 2001, "International competitive effects of harmonization" International Journal of Accounting, 36, No. 1, 1-32.

18. Leuz, C., 2003, "IAS versus US GAAP: Information asymmetry based evidence from Germany." Journal of Accounting Research, 41, No. 3, 445-472.

20. Merei, I., 1985, "Design and application of professional standards in a developing country; the case in Saudi Arabia." In V.K. Zimmerman (ed.), The Recent Accounting and Auditing Developments in the Middle East. Urbana-Champaign: University of Illinois. 43-63.

21. Mutter, C., 1993 "Evaluation of the actual disclosure level in the financial statements of Jordanian companies" Dirasat, 20, No. 2, 271-283.

22. Ndubizu, G., and R. Wallace, 2003, "Contracts valuation assessment noise and cross-border listing of equities on U.S. and U.K. stock markets.” International Journal of Accounting, Vol. 38, No. 4, 397-421.

23. Purvis, S., H. Gernon, and M. Diamond, 1991 "The IASC and its Comparability Project: Prerequisites for Success." Accounting Horizons.

24. Richardson, A., and I. Hutchinson, 1999, "The case of International Accounting Standards in Canada: A Detailed Report" Certified General Accountants Association of Canada.

25. Samuels, I., and J. Oliga, 1982, “Accounting standards in developing countries,” The International Journal of Accounting, 18, No. 1, 69-88.

26. Walter, I., 1993, "Emerging Equity Markets.” ASEAN Economic Bulletin, July, 10 No. 1, 1-19. 
Notes 